\title{
OBESITY AND CANCER
}

\author{
FRANJO CMREČAK ${ }^{1}$, IVA ANDRAŠEK ${ }^{1}$, \\ VIŠNJA GREGOV ${ }^{1}$ and LIDIJA BEKETIĆ-OREŠKOVIĆ ${ }^{1,2}$ \\ ${ }^{1}$ Division of Oncology and Radiotherapy. University Hospital for Tumors, \\ Sestre milosrdnice University Hospital Center, Zagreb, Croatia; \\ ${ }^{2}$ Department of Clinical Oncology, School of Medicine University of Zagreb, Zagreb, Croatia
}

\section{Summary}

For the past several decades, we have witnessed the emergence of the obesity pandemic worldwide and, simultaneously, the increase of incidence of malignant diseases. The effects of obesity and overweight on cancer incidence, morbidity, and mortality started to be meticulously researched only recently. According to the epidemiological data analysis, the connection between obesity and increased risk of numerous cancers has been established. Estimations are that a change in lifestyle and diet can prevent $30-50 \%$ of malignant diseases. After smoking, obesity is the second largest preventable cause of cancer. Obesity affects the quality of life and increases the risk of cancer recurrence and cancer-related mortality. By reducing body mass and avoiding gaining weight during adulthood, the risk of getting cancer is lowered. Numerous studies have shown the beneficial effects of physical activity during and after cancer treatment. Obesity influences cancer development; however, the mechanisms responsible for it are still unclear. It is considered that chronic inflammation, caused by the overabundance of nutrients, increases the levels of inflammatory cytokines and immune cells. It has been discovered that adipocytes have an important endocrine role; they synthesize numerous hormones and adipocytokines, such as leptin and adiponectin. High levels of leptons and low levels of adiponectin can activate intracellular signaling pathways involving malignant cells' development. An important part of cancer development can be attributed to insulin metabolism, insulin-like growth factors, and sex hormones.

KEYWORDS: obesity, cancer, mechanisms

\section{INTRODUCTION}

Obesity is a complex multifactorial disease, which can be defined as an abnormal and excessive accumulation of fat tissue in the body with a consequent adverse effect on the human body's health. The body mass index (BMI) is the most

\footnotetext{
Corresponding author: Lidija Beketić-Orešković, Department of Clinical Oncology, School of Medicine University of Zagreb and Division of Oncology and Radiotherapy, University Hospital for Tumors, Sestre milosrdnice University Hospital Center, Ilica 197, Zagreb, Croatia.

e-mail: lidijabeketicoreskovic@gmail.com
}

commonly used scale to measure nutritional status. It is calculated by dividing a person's weight (in kilograms) by their height (meters) squared. $\mathrm{BMI}$ is expressed in units of $\mathrm{kg} / \mathrm{m}^{2}$. According to $\mathrm{WHO}, \mathrm{BMI}$ values fall into four basic categories. People with a BMI below $18.5 \mathrm{~kg} / \mathrm{m}^{2}$ are considered underweight. Between 18.5 and $24.9 \mathrm{~kg} / \mathrm{m}^{2}$ are considered normal body weight, overweight more than $25 \mathrm{~kg} / \mathrm{m}^{2}$, and obese with more than 30 $\mathrm{kg} / \mathrm{m}^{2}$. Obesity can be further subdivided into class I obesity with BMI $30-34.9 \mathrm{~kg} / \mathrm{m}^{2}$, class II obesity with BMI $35-39.9 \mathrm{~kg} / \mathrm{m}^{2}$, and class III obesity with BMI $>40 \mathrm{~kg} / \mathrm{m}^{2}$. Class III obesity is sometimes 
categorized as extreme obesity. Complementing the BMI, waist circumference, and waist-hip ratio are increasingly used to assess body fat distribution. The waist-hip ratio is the number obtained by dividing the waist and hips circumference. Waist circumference is a better predictor of visceral adipose tissue than BMI in both genders. Abdominal adiposity can vary significantly within a small range of BMI and total body fat. Excessive visceral adipose tissue is associated with decreased adiponectin levels, elevated levels of cytokines (IL-6, TNF- $\alpha$ ), insulin resistance, systemic inflammation (1). In 2015, there were an estimated 603 million obese adults and 107 million obese children worldwide (2). WHO has extracted several key facts on obesity; since 1975, worldwide obesity has nearly tripled, more than 1.9 billion adults or $39 \%$ of adults were overweight, and over 650 million or $13 \%$ of adults were obese. Forty million children under the age of 5 and over 340 million children between the ages of 5 and 19 were obese or overweight-overweight and obese kill more people than underweight (3). In Croatia, according to the $2015 / 2016$ survey, $34.9 \%$ of children aged 8-9 were overweight and obese (4). The overall prevalence of overweight in Croatia is estimated at $38.11 \%$ and obesity at $20.34 \%$. For men, the prevalence of overweight is $43.2 \%$, obesity $20.1 \%$, and for women, the prevalence of overweight $33.6 \%$ and obesity $20.6 \%$ (5). Obesity has assumed pandemic proportions. The obesity pandemic can be explained by a drastic change in lifestyle and living environment in the last 30 years. Modern societies practice a sedentary lifestyle, consume processed, cheap, and high-calorie foods, live in urbanized and industrialized environments with massive use of mechanized transport. Obesity is associated with numerous diseases and conditions such as type II diabetes mellitus, hypertension, hypothyroidism, dyslipidemia, stroke, coronary heart disease, obstructive sleep apnea, cholelithiasis, osteoarthritis, and depression (6). Through an extensive review of the literature, many epidemiological studies have linked obesity to an increased risk of many cancer types. Obesity has been shown to increase the risk of oesophageal adenocarcinoma, gastric cardia cancer, colorectal cancer, pancreatic cancer, liver cancer, and gall bladder cancer, endometrial cancer, postmenopausal breast cancer, ovary, kidney, and thyroid cancers, meningioma, and multiple myeloma. Modern society pays a substantial economic and psychosocial price due to obesity. In 2008, total national spending caused by obesity and overweight in the U.S. was estimated at over $\$ 140$ billion or nearly $10 \%$ of all medical expenses (7). Avoiding weight gain during adulthood may protect overweight and obese individuals from certain types of cancer. According to meta-analysis, weight gain during adulthood is associated with a higher risk of colon and kidney cancer and postmenopausal women of breast, ovarian, and endometrial cancers (8). There is also evidence that weight loss also reduces the risk of obesity-related cancers. Obese patients undergoing bariatric surgery had a $45 \%$ lower risk of developing obesityrelated cancer in comparison with the obese control group (9).

The mechanisms by which obesity increases the risk of cancer are not completely clear. It is thought to be related to significant metabolic and hormonal disorders. Obesity is associated with changes in the metabolism of sex hormones, insulin and insulin-like growth factor signaling, chronic inflammation, and adipokine disorders.

Cancer is the second leading cause of death in the world. In 2018, the cancer occurrence rate was estimated at 18.1 million new cases and 9.6 million cancer-related deaths. The most commonly diagnosed cancer was lung cancer $(11.6 \%$ of new cases), followed by breast cancer (also $11.6 \%$ of cases), prostate cancer $(7.1 \%)$, and colorectal cancer $(6.1 \%)$. Lung cancer has the highest mortality rate and contributes to $18.4 \%$ of all cancer deaths. Colorectal cancer accounts for $9.2 \%$, stomach cancer for $8.2 \%$, and liver cancer for $8.2 \%$ of total cancer deaths. Breast cancer is the most common cancer and the leading cause of cancer deaths among women ( $6.6 \%$ of all cancer deaths) (10). It is estimated that between 30 and $50 \%$ of all cancer and cancer-related deaths could be prevented by diet and lifestyle changes. The two most common modifiable causes of cancer are tobacco use and obesity/overweight. Other preventable risk factors that affect the incidence and mortality of cancer are alcohol consumption, diet, physical inactivity, occupation, infections, pollution, U.V., and ionizing radiation (11).

\section{MECHANISMS}

As stated above, obesity and overweight are risk factors for the occurrence of certain cancers. 
There are several hypotheses on possible mechanisms. Over the past decades, an association between rapid growth in obesity and type II diabetes mellitus has been noticed, with the finding of insulin resistance, consequent hyperinsulinemia, and impaired glucose homeostasis in such patients. Further research has revealed insulin resistance in various infections and acute immune conditions, such as sepsis, HIV, hepatitis, rheumatoid arthritis $(12,13,14,15)$.

Thus, it seems that metabolic tissues such as adipose tissue, liver, and muscles interacted with the immune system. The classic inflammatory reaction is defined by pain, redness, heat, and swelling. A different inflammatory response was found in obese individuals, and the term metainflammation was proposed. The trigger for an immune response in obesity is a metabolic cell (adipocyte) in response to excessive nutrient intake. Full-spectrum of inflammatory cytokines is secreted in adipose tissue, followed by increased numbers of macrophages, natural killer T cells, mast cells, and CD8/CD4 lymphocytes $(16,17)$. In summary, obesity-induced chronic, low to moderate inflammation, and nutrient-induced inflammatory response initiated by metabolic cells creates a specific milieu of various immune cells and proinflammatory cytokines. Chronic inflammatory microenvironment can cause direct DNA damage by increasing oxidative stress, tumor promotion, and progression by promoting neoangiogenesis, growth, and invasion of tumor cells $(18,19,20)$.

Gallstones are a common complication of obesity, which triples the risk of gallstones in women and doubles it in men, adults, and adolescents (21). In obesity, the activity of cholesterol synthesis and secretion into bile is increased (22). Gallstones appear to carry the highest risk for gallbladder cancer with a relative risk of 4.9 (23). Chronic irritation of gallbladder mucosa caused by gallstones and deposition of calcium in the gallbladder wall (porcelain gallbladder) leads to dysplasia and can end with malignant transformation $(24,25)$. In Barrett's esophagus, prolonged acid exposure in gastroesophageal reflux disease (GERD) leads to chronic inflammation and replacement of healthy oesophageal epithelium with metaplastic columnar cells. Prolonged exposure to gastric acid and bile salts to induce nitric oxide and reactive oxygen species, which causes double-strand breakage and oxidative DNA dam- age. These events prompt metaplasia and dysplasia to cancer sequence (26). The relative risk of adenocarcinoma among patients with Barrett's esophagus compared to the general population was 11.3, and the annual risk of adenocarcinoma was $0.12 \%$ (27).

A prime example of the association between chronic inflammation and cancer is liver cancer. Hepatocellular carcinoma is the most common form of primary liver cancer, the fifth most common type of cancer globally, and the third cause of cancer-related death in the world (28). Most hepatocellular carcinoma cases are associated with chronic viral hepatitis caused by hepatitis B and C, excessive alcohol consumption, non-alcoholic steatohepatitis, and hemochromatosis (29). During chronic viral infection, the host immune system often fails to eradicate the infection, culminating in a continuous cycle of necrosis and hepatocyte regeneration, increasing the likelihood of gene mutations in hepatocytes and initiates the proliferation survival of the affected cells. Oxidative stress, inflammatory cells, and cytokines induce oxidative damage to DNA, DNA methylation, transcription, and activation of growth factors, thus accelerating hepatocarcinogenesis (30). In obese individuals, the inflammatory cascade and insulin resistance are thought to play a significant role in developing liver cancer (31).

Repeated flare-ups of inflammation of the colorectum's mucous membranes in ulcerative colitis increase cancer's likelihood by inducing oxidative DNA damage, DNA methylation, microsatellite instability, mutation of the p53 gene, and mitochondrial DNA, and inhibition of suppressor oncogenes $(32,33)$.

Another possible mechanism to explain the increased risk of cancer in obese individuals is the influence of various hormones and growth factors synthesized and released by adipocytes. These new hormones, or so-called adipocytokines, have a potentially important role in food intake and energy balance. The role of many adipocytokines is still unclear. The best known and most studied adipocytokine is leptin. Leptin is a 167-amino acid peptide hormone secreted by adipocytes and allows communication between adipose tissue and the central nervous system. It binds to the leptin receptor (known as LEP-R or Ob-R) in presynaptic GABAnergic neurons of the hypothalamus, decreasing food intake and promoting energy con- 
sumption. During fasting, dieting, or uncontrolled type I diabetes, fat deposits are reduced, leptin levels in serum decrease, stimulate hunger, and reduce energy consumption-genetic deficiency of leptin results in massive obesity with extreme hyperphagia and reduced energy expenditure. The serum concentration of leptin is proportional to the amount of fat in the body. Therefore, higher leptin concentration should result in decreased food intake and raised energy expenditure, which is not the case in obese and overweight patients, suggesting a leptin resistance state. (34).

Several possible mechanisms for the development of leptin resistance include genetic mutations, impaired leptin transport across the bloodbrain barrier, dysregulation of leptin expression, hypothalamic inflammation (35). Besides insulin, leptin plays a vital metabolic role by decreasing hepatic glucose production, increasing insulin sensitivity, decreasing glucagon levels, decreasing insulin synthesis and secretion, and decreasing lipogenesis in adipose tissue (36). Leptin receptors are usually found in the brain but also in many peripheral organs Leptin activates numerous intracellular signaling pathways like Jak/Stat, MAPK, PI3K/Akt, and SOCS pathways promote cancer cell growth and metastases. Increased expression of the ObR receptor has been detected in breast and gastrointestinal cancers and is associated with poorer prognosis (37).

Adiponectin is a protein hormone, and it is primarily synthesized in adipose tissue. Obese individuals generally have decreased adiponectin levels, while weight loss increases adiponectin levels. Hypoadiponectinemia is associated with insulin resistance, dyslipidemia, and atherosclerosis. It has a significant role in suppressing the action of inflammatory cytokines and modulates natural killer cells. Unlike leptin, adiponectin appears to have anti-tumor effects. Attachment of adiponectin to AdipoR1 and AdipoR2 receptors increases AMPK phosphorylation and counteracts leptin signaling. In some cases, adiponectin can reduce migration and invasion of tumor cells, suppress breast cancer xenografts' growth, and inhibit tumor neoangiogenesis (38). Some studies have found that low adiponectin levels are associated with an increased risk for gastric, prostate, and non-small cell lung cancer $(39,40,41)$.

Estrogens are essential in adipose tissue distribution, body weight, energy expenditure, and metabolism. Studies have shown that estrogens play a significant role in the proliferation of the healthy and neoplastic epithelium and that they have carcinogenic effects in breast cancer development. Estrogens have a carcinogenic effect on the cell in three ways: by stimulating cell proliferation via estrogen receptors and direct genotoxic effects by increasing mutation rates via activation of cytochrome p450 and induction of aneuploidy (42). The vast majority of estrogens are produced in healthy, premenopausal women in the ovaries via aromatization of androstenedione to estrone and estradiol. However, in postmenopausal women and men, most estrogens are synthesized in extragonadal sites, mainly in adipose tissue from androgenic precursors. Estrogen levels are proportional, dependent on the amount of adipose tissue. Obesity is a known risk factor for the progression and development of breast cancer among postmenopausal women. According to studies, the risk of death from breast cancer is 2.28 times greater for women classified as obese, and for each $5 \mathrm{~kg}$ gain in weight, breast cancer mortality is increased by $13 \%$. In summary, obese and overweight women and women who gain weight are associated with higher breast cancer mortality (43). Besides breast cancer, high estrogen levels have been associated with an increased risk of endometrial and ovarian cancers $(44,45)$.

Obesity and type II diabetes are closely related and show increased prevalence worldwide. Obese patients and diabetics have increased mortality and incidence of numerous cancers. Diabetes is a disease characterized by many metabolic disorders that contribute to cancer progressions such as hyperinsulinemia, dyslipidemia, hyperglycemia, elevated levels of free insulin-like growth factor I, changes in adipokine, and cytokine secretion. Hyperinsulinemia or insulin resistance is present in almost all individuals with type II diabetes and correlates positively with abdominal obesity (46). Many tumors express IGF-I, which is the ligand for IGF-IR. In animal models, high doses of IGF-I stimulates cancer growth and metastases (47). The insulin receptor (I.R.) is also overexpressed by many different cancers like breast, colon, lung, prostate, ovary, and thyroid cancers. It seems that hyperinsulinemia may contribute to tumor growth and progression by binding with I.R., which activates complex metabolic and mitogenic pathways. 
Furthermore, epidemiological studies have shown a positive association between elevated cpeptide levels (a marker of insulin secretion) and breast, colorectal and endometrial cancers $(48,49,50)$.

\section{Endometrial cancer and obesity}

Traditionally, endometrial cancers are divided according to histology and disease outcome into two types. Type I tumors account for the majority of all endometrial cancers, mostly endometrioid adenocarcinoma. It often arises from endometrial hyperplasia and is associated with higher estrogen levels. Type II tumors are predominantly serous, or clear-cell cancers, which are often described as estrogen-independent from the atrophic endometrium. Type II tumors have a worse prognosis and less differentiation than type I tumors. Among the risk factors for the development of type I endometrial cancer, there is an imbalance between estrogen and progesterone exposure, including obesity and the use of unopposed estrogen therapy. A large study that included data from 24 cohort and case report studies, the aim was to clarify risk factors for the development of both types of endometrial cancer. Obese and overweight women are 2 to 4 times more likely to develop type I endometrial cancer than normal body weight women. Extremely obese women (BMI>40 $\mathrm{kg} / \mathrm{m}^{2}$ ) have an even 7-fold increased risk of developing endometrial cancer. Surprisingly, type II endometrial cancers also occur two to three times more frequently in obese and overweight women (51). In summary, it appears that both types of endometrial cancers have similar risk factor profiles, and both are associated with estrogenic and antiestrogenic exposure. Furthermore, obesity throughout life, including childhood and adolescence, is associated with endometrial cancer risk. Additionally, weight gain after 18 increases the risk of endometrial cancer compared to women of stable body weight (52)

\section{Oesophageal adenocarcinoma and obesity}

According to the epidemiological data, there has been a considerable increase in oesophageal adenocarcinoma incidence over the last 35 years. Among white men, increases in the incidence of oesophageal adenocarcinoma between 1975 and 2004 were staggering $463 \%$ and $335 \%$ among white women in the United States (53). Survival rates of patients with oesophageal carcinoma continue to be low despite better supportive care and treatment options. Obesity is associated with an increased risk of oesophageal adenocarcinoma, GERD, and Barrett's esophagus (54). Abdominal thickness increases intra-abdominal pressure and consequently increases GERD's propensity by deforming the lower oesophageal sphincter (55). An extensive analysis involving 12 epidemiological studies stressed an association of oesophageal adenocarcinomas and oesophagogastric junction adenocarcinomas with increasing BMI. Overweight and obese patients are twice as likely to develop oesophageal cancer than patients with normal body weight. Extremely obese patients $\left(\mathrm{BMI}>40 \mathrm{~kg} / \mathrm{m}^{2}\right.$ ) have an almost fivefold higher risk of developing oesophageal cancer than patients with $\mathrm{BMI}<25 \mathrm{~kg} / \mathrm{m}^{2}$. Similarly, an increase in BMI also increases the risk of developing oesophagogastric junction adenocarcinomas 2 to 3 times compared to a patient of normal body weight. The synergistic effect of obesity and GERD concerning oesophageal adenocarcinoma risk has also been demonstrated (56). Several potential mechanisms explain the association between obesity and oesophageal cancer. The first mechanism is direct or mechanical, where central obesity causes deformity of the oesophageal sphincter, increases intragastric pressure, and increases hiatal hernia and GERD risk. The second mechanism is an indirect, proinflammatory, carcinogenic pathway caused by adipose tissue's highly metabolic and hormonal activity (57).

\section{Gastric cancer and obesity}

Gastric cancer is the fifth most commonly diagnosed cancer and the second leading cause of cancer-related death (10). According to anatomical localization of the tumor, gastric cancers are classified into gastric non-cardia cancer (GNCS) and gastric cardia cancer (GCC). Interestingly, a decrease in the incidence of gastric non-cardia cancer and an increase in gastric cardia cancer incidence in western countries have been observed. Epidemiological studies have shown different etiological causes between the two subtypes, explaining the discrepancy of incidences. Risk factors for GCC may be GERD, white race, male gender, and tobacco smoking, while most GNCS can be linked to Helicobacter pylori infection, alcohol 
consumption, tobacco smoking, and use of salt or salted, pickled food (58-61). The rising incidence of many cancers and the parallel epidemic of obesity suggest an association between the two. A meta-analysis by Cheng et al. investigated the association between BMI increase and GCC and GNCC and evaluated 24 prospective studies that included 41,791 patients. The meta-analysis results showed a positive association with gastric cardia cancer risk with an increased BMI (GCC; for overweight patients, $S R R=1.21$, and obese $\mathrm{SRR}=1.82$ ). This meta-analysis found no association between increased risk for GNCC development and obesity (GNCC; for overweight patients, $\mathrm{SRR}=0.93$ and obese $\mathrm{SRR}=1.00)$. It is likely that the biological mechanism by which obesity increases gastric cardia cancer risk is similar to that of oesophageal adenocarcinoma (62).

\section{Liver cancer and obesity}

Primary liver cancer (PLC) is the sixth most common cancer globally and the second leading cause of cancer death in East Asia and sub-Saharan Africa. According to data, primary liver cancer incidence has tripled in the United States in the last four decades (10). The literature data describes numerous risk factors such as chronic viral hepatitis (hepatitis B and C), liver cirrhosis, aflatoxins, non-alcoholic fatty liver disease, alcohol consumption, smoking, obesity, diabetes mellitus. A metaanalysis published in 2012 analyzed data from 25337 liver cancer patients included in 26 prospective studies to assess the association between obesity and the risk of primary liver cancer. Results showed that excess body weight and obesity were associated with an increased risk of PLC. Overweight people (BMI> $25 \mathrm{~kg} / \mathrm{m}^{2}$ ) have a $48 \%$ higher risk of developing liver cancer than normal body weight subjects (SRR $=1.48)$. For obese individuals, this risk is twice as high (R.R. = 1.83). Subgroup analysis showed that the positive association between weight gain and liver cancer was independent of other risk factors. By stratifying the data for gender, it is observed that overweight males had a higher risk of PLC than overweight females (for males, $S R R=1.42$, for females, $S R R=$ 1.18). A similar difference is observed by comparing the risk of PLC development for obese males (SRR=1.91) and women (SRR=1.55) (63).

The Liver Cancer Association Project collected and analyzed 14 prospective studies from 1.57 million adults in the United States to investigate BMI, waist circumference, and type II diabetes with primary liver cancer risk, and identified 2162 patients diagnosed with primary liver cancer. Their average age was 58.2 years, mean BMI 26.6 $\mathrm{kg} / \mathrm{m}^{2}$, average waist circumference $89.8 \mathrm{~cm}$, and prevalence of type 2 diabetes $6.5 \%$. Compared with normal body weight, overweight has $21 \%$, class I obesity $87 \%$, class II obesity $142 \%$, class III obesity $116 \%$ higher risk of liver cancer. The analysis results also showed that type II diabetes triple the risk of liver cancer (HR=2.85) (64). These studies have demonstrated a clear association between obesity and type II diabetes with an increased risk of developing liver cancer. Adiposity and type II diabetes share common mechanisms involved in hepatocellular carcinogenesis. The increased amount of adipose tissue in the liver causes fibrosis and cirrhosis of the liver, lipotoxicity, lowgrade chronic inflammation, and insulin resistance (65). There is increasing evidence that both intestinal microbiota and activation of toll-like receptor (TLR4) by lipopolysaccharide (LPS) play a role in the promotion and proliferation of liver cancer (66). In obesity, alteration of gut microbiota increases deoxycholic acid levels in the enterohepatic circulation. Deoxycholic acid is known to cause DNA damage through oxidative stress, which provokes Ito cells in the liver to secrete various inflammatory and tumor-promoting factors (67).

\section{Renal cancer and obesity}

As with many cancers, an increase in kidney cancer incidence has been observed; it could be associated with arterial hypertension, obesity, and smoking as risk factors (68). About $80-90 \%$ of all kidney cancers are renal cell carcinoma (RCC). Locoregional and metastatic disease of kidney cancer is common at diagnosis because of a lack of early signs and symptoms in patients. In 2014, a comprehensive meta-analysis of 21 cohort studies was published with 15144 cases of kidney cancer and more than 9 million participants. The study demonstrated an increased risk of kidney cancer in obese and overweight patients. The relative risk of RCC in overweight patients was 1.28 and 1.77 in obese patients. Overweight and obese women had a slightly higher risk of RCC than men. The risk of RCC for men and women increased by $4 \%$ and $5 \%$, respectively, for each $1 \mathrm{~kg} / \mathrm{m} 2$ increment (69). 
An extensive 2014 study analyzed data from 156.774 participants over 10.8 years on the relationship between hypertension, obesity, and kidney cancer. Data showed an excessive risk of kidney cancer in both sexes with increasing blood pressure. Also, the association between obesity and kidney cancer is independent of its association with hypertension or smoking (70).

The mechanism by which obesity increases the risk of kidney cancer is not yet clear. A possible explanation is the complex interaction of insulin, increased insulin-like growth factors, sex hormones, and adipokines. Insulin-like growth factor and its pathway are essential for the von HippelLindau (VHL) tumor suppressor gene. In its deficiency, an autosomal dominant syndrome called VHL syndrome develops, marked by multiple renal cell tumors (71).

\section{Pancreatic cancer and obesity}

Pancreatic cancer, as kidney cancer has few early signs and symptoms, is diagnosed at late stages and has a 5-year survival of only $7 \%$ (72). The incidence of pancreatic cancer is exceptionally high in Western societies and increasing over the last few decades. Obesity is hypothesized to promote the growth of pancreatic cancer. Based on the analysis of 14 cohort studies on 846340 individuals with 2135 cases of pancreatic cancer, Genkinger et al. concluded that BMI is positively associated with pancreatic cancer risk. Obese individuals had a $47 \%$ higher risk of pancreatic cancer $($ R.R. $=1.47)$.

Furthermore, the analysis also found a positive association between being overweight in early adulthood and being obese at baseline, with a $54 \%$ increased risk of pancreatic cancer (R.R. $=1.54$ ). Also, an increase in BMI of more than $10 \mathrm{~kg} / \mathrm{m} 2$ compared to BMI in early adulthood has been shown to increase the risk of pancreatic cancer by $40 \%$ compared to persons of stable body weight (73). Multiple mechanisms and pathways are thought to be responsible for the increased risk of pancreatic cancer in the obese, such as insulin resistance, secretion, and synthesis of numerous hormones and adipocytokines, environmental exposure to carcinogens and mutagens in food, and decreased physical activity leading to energy imbalance (74).

\section{Breast cancer and obesity}

Breast cancer is the second most common cancer globally and the second cause of cancer-related death in more developed regions after lung cancer. Understanding how obesity affects breast cancer has important implications for public health. A comprehensive systematic review and meta-analysis published in 2007 analyzed data from 141 articles and included 282137 cancer cases to determine the risk of breast cancer associated with a BMI increase of $5 \mathrm{~kg} / \mathrm{m}^{2}$. In women, a meta-analysis found a strong association with BMI increase and endometrial $($ R.R. $=1.59)$, gallbladder $($ R.R. $=1.59)$, esophagus (R.R. $=1.51)$, and kidney cancers (R.R. = 1.34). A slightly lower positive correlation was found between weight gain by more than $>5 \mathrm{~kg} / \mathrm{m}^{2}$ and leukemia, pancreatic, thyroid, and postmenopausal breast cancers. The relative risk for postmenopausal breast cancer was 1.12, which means that every 5 unit increase in $\mathrm{BMI}$ is associated with a $12 \%$ increase in risk (75).

Earlier studies have noted a different association between obesity and menopausal status. In obese premenopausal women, the risk of premenopausal breast cancer was lower than that of normal-weight women. In contrast, in obese postmenopausal women, studies have reported an increased risk of postmenopausal breast cancer. $(75,76)$. It has also been observed that the use of postmenopausal hormone therapy can modify the association between postmenopausal breast cancer and obesity. Munsell et al. published in 2013 a comprehensive meta-analysis with an aim to analyze and evaluate the relationship between BMI, menopausal status, and breast cancer according to breast cancer subtype and the use of hormone replacement therapy. Twenty-two articles with 17407 participants analyzed the relationship between premenopausal breast cancer and body mass index. Overweight women (BMI 25-29.9 kg/ $\mathrm{m}^{2}$ ) were associated with modestly reduced risk of $5 \%$ (risk ratio, $\mathrm{RR}=0.95$ ) and obese women (BMI $>30 \mathrm{~kg} / \mathrm{m}^{2}$ ) with $17 \%$ reduced risk of premenopausal breast cancer $(\mathrm{RR}=0.83)$. While comparing obesity with breast cancer subtype, an association with E.R. positive/P.R. positive (R.R. $=0.78)$ but not with E.R. negative/P.R. negative cancer (R.R. = 1.06) was observed. In analyzing the relationship between obesity and postmenopausal breast cancer, the authors included 39 articles comprising 
59185 participants with breast cancer. Overweight and obese women were associated with a $10 \%$ and $18 \%$ increased risk of postmenopausal breast cancer, respectively. Similar to premenopausal breast cancer, only E.R. positive / P.R. positive breast cancer has been shown to be associated with obesity. A $40 \%$ higher risk of developing postmenopausal breast cancer due to obesity was observed in this subtype of breast cancer (R.R. = 1.39), while E.R. negative/P.R. negative postmenopausal breast cancer showed no association with obesity $(R R=0.98)$. Postmenopausal women who have never taken estrogen-progestin therapy were also found to be at higher risk of developing breast cancer than normal-weight women (R.R. = 1.42). Among obese ever users of estrogen-progestin therapy, association with an increased risk of postmenopausal cancer has not been found $(R R=0.98)$ than a normal-weight woman (77). In conclusion, a meta-analysis showed that obese women have a $20 \%$ reduction of hormone-receptor-positive premenopausal breast cancer relative risk and $20-40 \%$ increased risk of hormone-receptor-positive postmenopausal breast cancer in comparison with normal BMI women. It appears that the risk ratio is minimized for hormone receptornegative breast cancer and postmenopausal breast cancer among women using estrogen-progestin therapy.

Obesity is also a risk factor for breast cancer in men. In 2014, Brinton et al. evaluated 11 casecontrol and ten cohort investigations with 2405 breast cancer cases in men and 52013 control subjects to identify risk factors. Compared with men of normal body weight, obese men had a 30\% higher risk of developing breast cancer $(\mathrm{OR}=$ 1.35), almost identical to the postmenopausal breast cancer risk. The highest risk for developing breast cancer was observed in patients with Klinefelter syndrome $(\mathrm{OR}=24.7)$ and gynecomastia $(\mathrm{OR}=9.78)$ independently of BMI. Both Klinefelter syndrome and gynecomastia are linked with estrogen excess (78).

The biological mechanism that explains the association between obesity and breast cancer has been linked to the metabolism and action of sex hormones, most notably estrogen. Estradiol and estrone are elevated in postmenopausal obese women because they are secreted by adipose tissue via aromatization of androgenic precursors. On the other hand, obesity is associated with an- ovulation, thus explaining the lower levels of circulating estrogen in premenopause (79). The lower risk of breast cancer in patients receiving hormone therapy is explained by higher circulating estrogen levels and minimizing adipose tissue estrogen production.

\section{Biliary tract cancer and obesity}

Biliary tract cancer can be divided into two categories; more common gallbladder cancer (GBC) and less common extrahepatic bile duct cancer (EBDC). Gallbladder cancer is the sixth most common gastrointestinal tract cancer. It is characterized by late diagnosis and poor prognosis; the five-year survival of gallbladder cancer limited to gallbladder mucosa is only $32 \%$, while in the case of advanced gallbladder cancer, the one-year survival is merely $10 \%(80)$. Because of the importance of primary prevention, it is important to identify modifiable risk factors. Some early observational studies have shown an association between gallbladder cancer and increased BMI with inconsistent results. In a large meta-analysis from 2016, Li and colleagues investigated the association between overweight and obesity and biliary tract cancer risk. More than eleven and a half million participants were included in the meta-analysis, including 6733 patients with gallbladder cancer and 5798 patients with extrahepatic duct cancer. Results showed that excessive body weight is significantly associated with an increased risk of both GBC and EBDC. Among overweight patients, the risk of GBC and EBDC was $17 \%$ and $26 \%$ higher than normal-weight participants. For obese patients, the risk was higher; GBC's risk was $62 \%$, and the risk of EBDC was $48 \%$. The study showed that the increased risk is more pronounced in overweight and obese women and European populations (81). The association between cholelithiasis and gallbladder cancer has been known for decades, and adiposity is one of the major factors that increase gallstone formation. A hypothesis is that chronic inflammation, trauma, and infection can cause epithelial dysplasia and adenocarcinoma. Other possible mechanisms include increased levels of sex and metabolic hormones (80).

\section{Colorectal cancer and obesity}

Modifiable risk factors for one of the most common cancers globally, colorectal cancer, in- 
clude obesity, smoking, physical inactivity, and a low-fiber/high-fat diet. With the increasing incidence of obesity worldwide, understanding the correlation between colorectal cancer and obesity is becoming increasingly important. The metaanalysis published in 2013 included over 9 million participants and 90,000 cases of colorectal cancer, intending to establish an association between obesity, central adiposity, and risk of colorectal cancer. Obesity was measured using BMI and central adiposity by measuring waist circumference. Overall results showed a positive association between obesity and colorectal cancer, and the risk was $30 \%$ higher for obese compared to normalweight individuals. Higher waist circumference has also been shown to carry a higher risk of cancer (R.R. =1,455). Analysis of the data stratified by anatomical localization implies that elevated BMI and W.C. values caused an equally increased risk for rectal and colon cancers. Stratifying by sex, the risk for colorectal cancer in obese men was higher than in obese women ( $46 \%$ vs. $15 \%$ ) (82). As with other cancers, the exact mechanism of the impact of obesity on cancer development is not yet clear. Two possible hormonal mechanisms are suggested: insulin / insulin-like growth factor (IGF) axis and adipokines. High levels of total IGF1 are associated with an increased risk of advanced colorectal adenoma and cancer. Adipocytes could also promote cancer proliferation by the secretion of adipokines such as adiponectin and leptin, which are associated with the risk of colorectal cancer $(83,84)$.

\section{Benefit from weight loss and cancer risk reduction}

Evidence for an association between cancer and obesity was predominantly obtained from studies that determined excess body weight and weight gain, rather than studies that linked weight loss to a reduced risk of cancer. A small number of studies have compared weight loss and cancer risk and distinguish unintentional from intentional weight loss. Unintentional weight loss is often a sign of underlying health problems. It often happens that weight loss itself is challenging to sustain over several years. Preclinical studies have proven that weight loss can reduce cancer incidence by reducing oxidative damage to DNA, improving DNA repair, and affecting hormonal pathways (85).
Avoiding gaining weight during adulthood is associated with reducing kidney and colon cancer risk and in postmenopausal women with a risk reduction of breast, ovarian, and endometrial cancer (86).

The most robust evidence linking weight loss to a reduced risk of cancer comes from studies that followed patients who underwent bariatric surgery. Several studies have shown that weight loss after bariatric surgery statistically significantly reduces cancer risk $(87,88)$.

According to one study that compared the risk of endometrial cancer in postmenopausal women who had stable body weight $(+/-5 \%)$ and women with intentional weight loss $(>5 \%)$, results showed that women with weight loss had a 30\% lower risk of endometrial cancer. Analyzing the subgroups, the most significant benefit in reducing endometrial cancer risk was among obese women who lost weight $($ H.R. $=0.44)(89)$.

\section{Impact of obesity on cancer survivorship}

There is little data on the impact of obesity on cancer survival; most of the evidence comes from patients diagnosed with breast, colorectal, and prostate cancer. Research has shown that obesity affects the deterioration of life quality, higher rates of cancer recurrence and mortality, and increased risk for common adverse treatment effects.

In a cohort study conducted in 2003, excessive body mass was associated with increased death rates for all cancers combined and cancers at multiple specific sites (90).

Obese men who have prostate cancer have a higher risk of aggressive and fatal disease, a higher mortality rate, a higher risk of relapse, and it is initially more challenging to diagnose and detect prostate cancer $(91,92)$. In breast cancer survivors, overweight and obesity are associated with an increased risk of cancer-related lymphedema (90).

The beneficial effects of exercise in oncology patients should not be overlooked. Many studies have shown the beneficial effects of physical activity during and after cancer treatment. Exercise is associated with improvements in quality of life, physical function, and psychosocial outcomes. In breast and colon cancer survivors, higher physical activity is associated with a lower disease recurrence rate, cancer-specific mortality, and overall mortality (93). 


\section{CONCLUSION}

Cancer is a complex disease of pandemic proportions, caused by the interaction of a number of genetic and environmental factors. A large proportion of cancers can be related to risk factors such as obesity, tobacco, alcohol. So far, several possible mechanisms have been discovered that could explain the effect of obesity on the initiation and promotion of malignant cells. Further research is essential to discover how some cancers are more obesity-related than others. More efforts are needed from the world community to educate the population about the risks and consequences of being overweight. The investing in prevention of obesity, smoking, and alcohol consumption while encouraging a healthy diet and exercise would reduce the pressure on health systems and bring significant economic and psychosocial benefits. According to the evidence, it is recommended to increase physical activity and avoid gaining weight for cancer patients. Obese people are advised to lose weight to reduce cancer risk.

Further research is needed to understand the complexity of immune, metabolic, and hormonal mechanisms of obesity and their impact on cancer development and progression. It is essential to investigate therapeutic interventions on weight and energy balance, the impact of consuming better quality food, increased physical activity on cancer risk, disease recurrence, and mortality. Literature provides little data about obesity effects on the therapy response, cancer recurrence, and longterm outcomes. Effective therapeutic protocols optimizing energy consumption, exercise, and weight balance are needed for patients at risk of cancer or already have cancer.

\section{REFERENCES}

1. Scheid MP, Sweeney G. The role of adiponectin signaling in metabolic syndrome and cancer. Rev Endocr Metab Disord. 2014;15(2):157-67.

2. GBD 2015 Obesity Collaborators, Afshin A, Forouzanfar $\mathrm{MH}$, et al. Health Effects of Overweight and Obesity in 195 Countries over 25 Years. N Engl J Med. 2017;377(1):13-27.

3. WHO. Available from: https://www.who.int/en/newsroom/fact-sheets/detail/obesity-and-overweight.

4. Childhood obesity surveillance initiative, Croatia 2015/2016 (CroCOSI). Available from: https://www.
hzjz.hr/wp-content/uploads/2018/05/CroCOSI-izvjesce-EN-web.pdf.

5. Fišter K, Kolčić I, Musić Milanović S, Kern J. The Prevalence of Overweight, Obesity and Central Obesity in Six Regions of Croatia: Results from the Croatian Adult Health Survey. Collegium antropologicum. 2009;33 Supplement 1(1):25-29.

6. Apovian CM. Obesity: definition, comorbidities, causes, and burden. Am J Manag Care. 2016;22(7 Suppl): s176-85.

7. Hammond RA, Levine R. The economic impact of obesity in the United States. Diabetes Metab Syndr Obes. 2010;3:285-95.

8. Keum N, Greenwood DC, Lee DH, Kim R, Aune D, Ju W, Hu FB, Giovannucci EL. Adult weight gain and adiposity-related cancers: a dose-response meta-analysis of prospective observational studies. J Natl Cancer Inst. 2015;107(2).

9. Tee MC, Cao Y, Warnock GL, Hu FB, Chavarro JE. Effect of bariatric surgery on oncologic outcomes: a systematic review and meta-analysis. Surg Endosc. 2013; 27(12):4449-56.

10. Bray F, Ferlay J, Soerjomataram I, Siegel RL, Torre LA, Jemal A. Global cancer statistics 2018: GLOBOCAN estimates of incidence and mortality worldwide for 36 cancers in 185 countries. CA Cancer J Clin. 2018;68 (6):394-424.

11. Colditz GA, Wolin KY, Gehlert S. Applying what we know to accelerate cancer prevention. Sci Transl Med. 2012;4(127):127rv4.

12. Bahtiyar G, Shin JJ, Aytaman A, Sowers JR, McFarlane SI. 2004. Association of diabetes and hepatitis C infection: epidemiologic evidence and pathophysiologic insights. Curr. Diabetes Rep. 4:194-98.

13. Wichterman KA, Chaudry IH, Baue AE. 1979. Studies of peripheral glucose uptake during sepsis. Arch. Surg. 114:740-45.

14. Pao V, Lee GA, Grunfeld C. 2008. HIV therapy, metabolic syndrome, and cardiovascular risk. Curr. Atheroscler. Rep. 10:61-70.

15. Sidiropoulos PI, Karvounaris SA, Boumpas DT. 2008. Metabolic syndrome in rheumatic diseases: epidemiology, pathophysiology, and clinical implications. Arthritis Res. Ther. 10:207.

16. Berg AH, Scherer PE. 2005. Adipose tissue, inflammation, and cardiovascular disease. Circ. Res. 96:939-49.

17. Ohmura K, IshimoriN,Ohmura Y,Tokuhara S,Nozawa A, et al. 2010. Natural killerTcells are involved in adipose tissues inflammation and glucose intolerance in diet-induced obese mice. Arterioscler. Thromb. Vasc. Biol. 30:193-99

18. Gregor MF, Hotamisligil GS. Inflammatory mechanisms in obesity. Annu Rev Immunol. 2011;29:415-45.

19. van der Woude CJ, Kleibeuker JH, Jansen PL, Moshage H. Chronic inflammation, apoptosis and (pre-)malignant lesions in the gastro-intestinal tract. Apoptosis. 2004 Mar;9(2):123-30. 
20. O'Connor PM, Lapointe TK, Beck PL, Buret AG. Mechanisms by which inflammation may increase intestinal cancer risk in inflammatory bowel disease. Inflamm Bowel Dis. 2010;16(8):1411-20.

21. Alexandre Pariente, Serge Erlinger. Cholelithiasis and obesity: epidemiology, pathophysiology, clinical manifestations and prevention. Hépato-Gastro \& Oncologie Digestive. 2017;24(1):18-25.

22. Lambou-Gianoukos S, Heller SJ. Lithogenesis and bile metabolism. Surg Clin North Am. 2008;88:1175-1194.

23. Randi G, Franceschi S, La Vecchia C. Gallbladder cancer worldwide: geographical distribution and risk factors. Int J Cancer. 2006;118(7):1591-602.

24. Schnelldorfer, T. Porcelain Gallbladder: A Benign Process or Concern for Malignancy?. J Gastrointest Surg. 2013;17(6):1161-8.

25. Shaffer EA. Gallbladder cancer: the basics. Gastroenterol Hepatol (N Y). 2008;4(10):737-41.

26. Clemons NJ, McColl KE, Fitzgerald RC. Nitric oxide and acid induce double-strand DNA breaks in Barrett's esophagus carcinogenesis via distinct mechanisms. Gastroenterology. 2007;133(4):1198-209.

27. Hvid-Jensen F, Pedersen L, Drewes AM, Sørensen HT, Funch-Jensen P. Incidence of adenocarcinoma among patients with Barrett's esophagus. N Engl J Med. 2011365(15):1375-83.

28. Nordenstedt H, White DL, El-Serag HB. The changing pattern of epidemiology in hepatocellular carcinoma. Dig Liver Dis. 2010 Jul;42 Suppl 3:S206-14.

29. Bishayee A. The role of inflammation and liver cancer. Adv Exp Med Biol. 2014;816:401-35.

30. Marra M, Sordelli IM, Lombardi A, Lamberti M, Tarantino L, Giudice A, Stiuso P, Abbruzzese A, Sperlongano R, Accardo M, Agresti M, Caraglia M, Sperlongano P. Molecular targets and oxidative stress biomarkers in hepatocellular carcinoma: an overview. J Transl Med. 2011;9:171.

31. Shimizu M, Tanaka T, Moriwaki H. Obesity and hepatocellular carcinoma: targeting obesity-related inflammation for chemoprevention of liver carcinogenesis. Semin Immunopathol. 2013;35:191-202.

32. Jess T, Rungoe C, Peyrin-Biroulet L. Risk of colorectal cancer in patients with ulcerative colitis: a meta-analysis of population-based cohort studies. Clin Gastroenterol Hepatol. 2012;10(6):639-45.

33. Scarpa M, Castagliuolo I, Castoro C et al. Inflammatory colonic carcinogenesis: a review on pathogenesis and immunosurveillance mechanisms in ulcerative colitis. World J Gastroenterol. 2014;20(22):6774-85.

34. Ouchi N, Parker JL, Lugus JJ, Walsh K. Adipokines in inflammation and metabolic disease. Nat Rev Immunol. 2011;11(2):85-97.

35. Gruzdeva O, Borodkina D, Uchasova E, Dyleva Y, Barbarash $\mathrm{O}$. Leptin resistance: underlying mechanisms and diagnosis. Diabetes Metab Syndr Obes. 2019;12: 191-198.
36. Paz-Filho G, Mastronardi C, Wong ML, Licinio J. Leptin therapy, insulin sensitivity, and glucose homeostasis. Indian J Endocrinol Metab. 2012 Dec;16 (Suppl 3):S549-55.

37. Gallagher EJ, LeRoith D. Obesity and Diabetes: The Increased Risk of Cancer and Cancer-Related Mortality. Physiol Rev. 2015;95(3):727-748.

38. Surmacz E. Leptin and adiponectin: emerging therapeutic targets in breast cancer. J Mammary Gland Biol Neoplasia. 2013;18(3-4):321-32.

39. Ishikawa M, Kitayama J, Kazama S, Hiramatsu T, Hatano K, Nagawa H. Plasma adiponectin and gastric cancer. Clin Cancer Res. 2005;11(2 Pt 1):466-72.

40. Abdul-Ghafar J, Oh SS, Park SM, Wairagu P, Lee SN, Jeong Y, Eom M, Yong SJ, Jung SH. Expression of adiponectin receptor 1 is indicative of favorable prognosis in non-small cell lung carcinoma. Tohoku J Exp Med. 2013;229(2):153-62.

41. Michalakis K, Williams CJ, Mitsiades N, Blakeman J, Balafouta-Tselenis S, Giannopoulos A, Mantzoros CS. Serum adiponectin concentrations and tissue expression of adiponectin receptors are reduced in patients with prostate cancer: a case control study. Cancer Epidemiol Biomarkers Prev. 2007;16(2):308-13.

42. Russo J, Russo IH. The role of estrogen in the initiation of breast cancer. J Steroid Biochem Mol Biol. 2006; 102(1-5):89-96.

43. Nichols HB, Trentham-Dietz A, Egan KM, Titus-Ernstoff L, Holmes MD, Bersch AJ, Holick CN, Hampton JM, Stampfer MJ, Willett WC, Newcomb PA. Body mass index before and after breast cancer diagnosis: associations with all-cause, breast cancer, and cardiovascular disease mortality. Cancer Epidemiol Biomarkers Prev. 2009;18(5):1403-9.

44. Rodriguez AC, Blanchard Z, Maurer KA, Gertz J. Estrogen Signaling in Endometrial Cancer: a Key Oncogenic Pathway with Several Open Questions. Horm Cancer. 2019;10(2-3):51-63.

45. Kirilovas D, Schedvins K, Naessén T, Von Schoultz B, Carlström K. Conversion of circulating estrone sulfate to 17beta-estradiol by ovarian tumor tissue: a possible mechanism behind elevated circulating concentrations of 17 beta-estradiol in postmenopausal women with ovarian tumors. Gynecol Endocrinol. 2007;23(1): 25-8.

46. Reaven GM. Relationships among insulin resistance, type 2 diabetes, essential hypertension, and cardiovascular disease: similarities and differences. J Clin Hypertens (Greenwich). 2011;13(4):238-43.

47. Yakar S, Leroith D, Brodt P. The role of the growth hormone/insulin-like growth factor axis in tumor growth and progression: Lessons from animal models. Cytokine Growth Factor Rev. 2005;16(4-5):407-20.

48. Verheus M, Peeters PH, Rinaldi S et al. Serum C-peptide levels and breast cancer risk: results from the European Prospective Investigation into Cancer and Nutrition (EPIC). Int J Cancer. 2006;119(3):659-67. 
49. Jenab M, Riboli E, Cleveland RJ et al. Serum C-peptide, IGFBP-1 and IGFBP-2 and risk of colon and rectal cancers in the European Prospective Investigation into Cancer and Nutrition. Int J Cancer. 2007;121(2):368-76.

50. Lukanova A, Zeleniuch-Jacquotte A, Lundin E et al. Prediagnostic levels of C-peptide, IGF-I, IGFBP-1, -2 and -3 and risk of endometrial cancer. Int J Cancer 108: 262-268, 2004

51. Setiawan VW, Yang HP, Pike MC, et al. Type I and II endometrial cancers: have they different risk factors? J Clin Oncol. 2013;31(20):2607-18.

52. Dougan MM, Hankinson SE, Vivo ID, Tworoger SS, Glynn RJ, Michels KB. Prospective study of body size throughout the life-course and the incidence of endometrial cancer among premenopausal and postmenopausal women. Int J Cancer. 2015;137(3):625-37.

53. Brown LM, Devesa SS, Chow WH. Incidence of adenocarcinoma of the esophagus among white Americans by sex, stage, and age. J Natl Cancer Inst. 2008; 100(16):1184-7.

54. Lagergren J. Influence of obesity on the risk of esophageal disorders. Nat Rev Gastroenterol Hepatol. 2011; 8(6):340-7.

55. Corley DA, Kubo A. Body mass index and gastroesophageal reflux disease: a systematic review and meta-analysis. Am J Gastroenterol. 2006;101(11): 2619-28.

56. Hoyo C, Cook MB, Kamangar F, et al. Body mass index in relation to oesophageal and oesophagogastric junction adenocarcinomas: a pooled analysis from the International BEACON Consortium. Int J Epidemiol. 2012;41(6):1706-18.

57. Kubo A, Corley DA. Body mass index and adenocarcinomas of the esophagus or gastric cardia: a systematic review and meta-analysis. Cancer Epidemiol Biomarkers Prev. 2006;15(5):872-8.;

58. Kim HJ, Lim SY, Lee JS, Park S, Shin A, Choi BY, Shimazu T, Inoue M, Tsugane S, Kim J. Fresh and pickled vegetable consumption and gastric cancer in Japanese and Korean populations: a meta-analysis of observational studies. Cancer Sci. 2010;101(2):508-16.

59. Steevens J, Schouten LJ, Goldbohm RA, et al. Alcohol consumption, cigarette smoking and risk of subtypes of oesophageal and gastric cancer: a prospective cohort study. Gut 2010;59:39-48.;

60. Uemura N, Okamoto S, Yamamoto S, Matsumura N, Yamaguchi S, Yamakido M, Taniyama K, Sasaki N, Schlemper RJ. Helicobacter pylori infection and the development of gastric cancer. N Engl J Med. 2001 Sep 13;345(11):784-9.;

61. Sung NY, Choi KS, Park EC, Park K, Lee SY, Lee AK, Choi IJ, Jung KW, Won YJ, Shin HR. Smoking, alcohol and gastric cancer risk in Korean men: the National Health Insurance Corporation Study. Br J Cancer. 2007;97(5):700-4.

62. Chen Y, Liu L, Wang X, Wang J, Yan Z, Cheng J, Gong G, Li G. Body mass index and risk of gastric cancer: a meta-analysis of a population with more than ten million from 24 prospective studies. Cancer Epidemiol Biomarkers Prev. 2013;22(8):1395-408.

63. Chen Y, Wang X, Wang J, Yan Z, Luo J. Excess body weight and the risk of primary liver cancer: an updated meta-analysis of prospective studies. Eur J Cancer. 2012;48(14):2137-45.

64. Campbell PT, Newton CC, Freedman ND et al. Body Mass Index, Waist Circumference, Diabetes, and Risk of Liver Cancer for U.S. Adults. Cancer Res. 2016; 76(20):6076-83.

65. Lai S-W, Chen P-C, Liao K-F, Muo CH, Lin CC, Sung FC. Risk of Hepatocellular Carcinoma in Diabetic Patients and Risk Reduction Associated With Anti-Diabetic Therapy: A Population-Based Cohort Study. Am J Gastroenterol. 2011;107:46-52.

66. Darnaud M, Faivre J, Moniaux N. Targeting gut flora to prevent progression of hepatocellular carcinoma. J Hepatol. 2013;58(2):385-7.

67. Yoshimoto S, Loo TM, Atarashi K, Kanda H, Sato S et al. Obesity-induced gut microbial metabolite promotes liver cancer through senescence secretome. Nature. 2013;499(7456):97-101.

68. Cote ML, Colt JS, Schwartz KL, Wacholder S, Ruterbusch JJ, Davis F, Purdue M, Graubard BI, Chow WH. Cigarette smoking and renal cell carcinoma risk among black and white Americans: effect modification by hypertension and obesity. Cancer Epidemiol Biomarkers Prev. 2012;21(5):770-9.

69. Wang F, Xu Y. Body mass index and risk of renal cell cancer: a dose-response meta-analysis of published cohort studies. Int J Cancer. 2014;135(7):1673-86.

70. Sanfilippo KM, McTigue KM, Fidler CJ et al. Hypertension and obesity and the risk of kidney cancer in 2 large cohorts of US men and women. Hypertension. 2014;63(5):934-41.

71. Wilson KM, Cho E. Obesity and Kidney Cancer. Recent Results Cancer Res. 2016;208:81-93.

72. Lepage C, Capocaccia R, Hackl M, Lemmens V, Molina E et al.; EUROCARE-5 Working Group:. Survival in patients with primary liver cancer, gallbladder and extrahepatic biliary tract cancer and pancreatic cancer in Europe 1999-2007: Results of EUROCARE-5. Eur J Cancer. 2015;51(15):2169-78.

73. Genkinger JM, Spiegelman D, Anderson KE et al. A pooled analysis of 14 cohort studies of anthropometric factors and pancreatic cancer risk. Int J Cancer. 2011 Oct 1;129(7):1708-17.

74. Bracci PM. Obesity and pancreatic cancer: overview of epidemiologic evidence and biologic mechanisms. Mol Carcinog. 2012;51(1):53-63.

75. Renehan AG, Tyson M, Egger M, Heller RF, Zwahlen $M$. Body-mass index and incidence of cancer: a systematic review and meta-analysis of prospective observational studies. Lancet. 2008;371(9612):569-78.

76. Huang Z, Hankinson SE, Colditz GA, Stampfer MJ, Hunter DJ et al.. Dual effects of weight and weight gain on breast cancer risk. JAMA. 1997;278(17):1407-11. 
77. Munsell MF, Sprague BL, Berry DA, Chisholm G, Trentham-Dietz A. Body mass index and breast cancer risk according to postmenopausal estrogen-progestin use and hormone receptor status. Epidemiol Rev. 2014;36:114-36.

78. Brinton LA, Cook MB, McCormack V et al. Anthropometric and hormonal risk factors for male breast cancer: male breast cancer pooling project results [published correction appears in J Natl Cancer Inst. 2014;106(5):dju117]. J Natl Cancer Inst. 2014;106(3): djt465.

79. Potischman N, Swanson CA, Siiteri P et al. Reversal of relation between body mass and endogenous estrogen concentrations with menopausal status. J Natl Cancer Inst. 1996;88(11):756-758.

80. Lazcano-Ponce EC, Miquel JF, Muñoz N, Herrero R, Ferrecio $\mathrm{C}$ et al.. Epidemiology and molecular pathology of gallbladder cancer. CA Cancer J Clin. 2001; 51(6):349-64.

81. Li L, Gan Y, Li W, Wu C, Lu Z. Overweight, obesity and the risk of gallbladder and extrahepatic bile duct cancers: A meta-analysis of observational studies. Obesity (Silver Spring). 2016;24(8):1786-802.

82. Ma Y, Yang Y, Wang F, Zhang P, Shi C et al.. Obesity and risk of colorectal cancer: a systematic review of prospective studies. PLoS One. 2013;8(1):e53916.

83. Renehan AG, Frystyk J, Flyvbjerg A. Obesity and cancer risk: the role of the insulin-IGF axis. Trends Endocrinol Metab. 2006;17(8):328-36.

84. Stattin P, Lukanova A, Biessy C, Söderberg S, Palmqvist R, Kaaks R, Olsson T, Jellum E. Obesity and colon cancer: does leptin provide a link? Int J Cancer. 2004;109(1):149-52.

85. Kritchevsky D. Caloric restriction and experimental carcinogenesis. Toxicol Sci. 1999 Dec;52(2 Suppl):13-6. Review.
86. Keum N, Greenwood DC, Lee DH, Kim R, Aune D, Ju W, Hu FB, Giovannucci EL. Adult weight gain and adiposity-related cancers: a dose-response meta-analysis of prospective observational studies. J Natl Cancer Inst. 2015;107(2).

87. Schauer DP, Feigelson HS, Koebnick C, et al. Association Between Weight Loss and the Risk of Cancer after Bariatric Surgery. Obesity (Silver Spring). 2017;25 Suppl 2(Suppl 2):S52-S57.

88. Tee MC, Cao Y, Warnock GL, Hu FB, Chavarro JE. Effect of bariatric surgery on oncologic outcomes: a systematic review and meta-analysis. Surg Endosc. 2013 Dec;27(12):4449-56.

89. Luo J, Chlebowski RT, Hendryx M, Rohan T, Wactawski-Wende J, Thomson CA, Felix AS, Chen C, Barrington $\mathrm{W}$, Coday $\mathrm{M}$, Stefanick $\mathrm{M}$, LeBlanc E, Margolis KL. Intentional Weight Loss and Endometrial Cancer Risk. J Clin Oncol. 2017 Apr 10;35(11):1189-1193.

90. Calle EE, Rodriguez C, Walker-Thurmond K, Thun MJ. Overweight, obesity, and mortality from cancer in a prospectively studied cohort of U.S. adults. N Engl J Med. 2003 Apr 24;348(17):1625-38.

91. Freedland SJ, Platz EA. Obesity and prostate cancer: making sense out of apparently conflicting data. Epidemiol Rev. 2007;29:88-97.

92. Stroup SP, Cullen J, Auge BK, L'Esperance JO, Kang SK. Effect of obesity on prostate-specific antigen recurrence after radiation therapy for localized prostate cancer as measured by the 2006 Radiation Therapy Oncology Group-American Society for Therapeutic Radiation and Oncology (RTOG-ASTRO) Phoenix consensus definition. Cancer. 2007;110(5):1003-9.

93. Speed-Andrews AE, Courneya KS. Effects of exercise on quality of life and prognosis in cancer survivors. Curr Sports Med Rep. 2009;8(4):176-81. 


\section{Sažetak}

\section{PRETILOST I RAK}

\section{F. Cmrečak, I. Andrašek, V. Gregov i L. Beketić-Orešković}

Proteklih nekoliko desetljeća svjedočimo pandemiji pretilosti u cijelom svijetu i paralelnom porastu incidencije zloćudnih bolesti. Utjecaj pretilosti i prekomjerne tjelesne mase na incidenciju, morbiditet i mortalitet od raka tek $\mathrm{u}$ zadnjih nekoliko godina se počinje detaljnije istraživati. Prema analizama epidemioloških podataka, utvrđena je povezanost pretilosti s povećanim rizikom od nastanka mnogih tipova zloćudnih bolesti. Procjenjuje se da je oko 30-50\% zloćudnih bolesti moguće prevenirati promjenom načina života i dijetom. Nakon pušenja, pretilost je drugi vodeći preventabilni uzrok raka. Pretilost utječe na kvalitetu života, povećani rizik od povrata zloćudne bolesti i mortaliteta. Smanjenje tjelesne mase i izbjegavanje debljanja u odrasloj dobi se povezuje sa smanjenim rizikom od zloćudnih bolesti. Mnoge studije su pokazale blagotvorne učinke redovite tjelesne aktivnosti tijekom i nakon liječenja raka. Točni mehanizmi utjecaja pretilosti na razvoj zloćudnih bolesti još nisu jasni. Smatra se da postoji povezanost s kroničnom upalom uzrokovanom pretjeranim unosom nutrijenata i posljedičnim povećanim razinama inflamatornih citokina i imunosnih stanica. Otkriveno je da adipociti imaju važnu endokrinu ulogu te sintetiziraju brojne hormone i adipocitokine, među kojima su najistraživaniji leptin i adiponektin. Visoke razine leptina i niske razine adiponektina mogu aktivirati intracelularne signalne puteve povezane s pojavom zloćudnih stanica. U razvoju raka važnu ulogu može imati i metabolizam inzulina, te inzulinu-slični faktori rasta i spolni hormoni.

Ključne riječi: pretilost, rak, mehanizmi 